\title{
PENGARUH METODE INKUIRI TERBIMBING DAN PROYEK TERHADAP KEMAMPUAN BERPIKIR KRITIS BIOLOGI SISWA DI SMP SWASTA HKBP SIMANTIN PANE
}

\author{
Hasmi Syahputra Harahap ${ }^{1)}$, Julion Turnip ${ }^{2)}$, Al Khudri Sembiring ${ }^{3)}$ \\ ${ }^{11}$ FKIP Universitas Labuhanbatu \\ email: hasmi.putraharahap@gmail.com \\ ${ }^{2)}$ SMP Swasta HKBP Simantin Pane \\ email: j.turnip@yahoo.com \\ ${ }^{3)}$ FKIP Universitas Lancang Kuning \\ email:alkhudri_s@unilak.ac.id
}

\begin{abstract}
ABSTRAK: Penelitian ini bertujuan untuk mengetahui pengaruh metode pembelajaran terhadap kemampuan berpikir kritis Biologi siswa di kelas VIII SMP Swasta HKBP Simantin Pane Kabupaten Simalungun. Metode penelitian menggunakan kuasi eksperimen dengan sampel penelitian sebanyak 3 kelas yang ditentukan secara total sampling. Kelas VIII-A dibelajarkan dengan dengan metode Inkuiri Terbimbing, kelas VIII-B dibelajarkan dengan metode Proyek, dan kelas VIII-C (kontrol) dibelajarkan dengan metode Tradisional. Instrumen penelitian menggunakan instrument kemampuan berpikir kritis dengan menggunakan tes pilihan berganda. Teknik analisis data menggunakan Analisis Kovariat (ANAKOVA) pada taraf signifikan $\alpha=0,05$ dengan bantuan SPSS 21.0. Hasil penelitian menunjukkan bahwa ada pengaruh yang signifikan metode pembelajaran terhadap kemampuan berpikir kritis $(\mathrm{F}=34,519 ; \mathrm{P}=0,000)$. Kemampuan berpikir kritis siswa yang dibelajarkan dengan inkuiri terbimbing $(79,06 \pm 4,651)$ signifikan lebih tinggi dibandingkan dengan metode proyek $(72,06 \pm 4,134)$, maupun model tradisional $(69,70 \pm 5,459)$. Sebagai tindak lanjut dari hasil penelitian ini diharapkan kepada guru untuk dapat menerapkan model pembelajaran inkuiri terbimbing pada materi sistem peredaran darah pada manusia dalam upaya meningkatkan kemampuan berpikir kritis siswa.
\end{abstract}

Kata Kunci: Kemampuan Berpikir Kritis, Inkuiri Terbimbing, Proyek, dan

\section{Tradisional}

ABSTRACT: The study aimed to identify the method of learning on ability to think critically biology from the classroom VIII private schools HKBP Simantin Pane Simalungun district. The methodology using quasi experiments with the sample 3 class as an overall sampling. Class VIII-A inlearn with, tutorial inkuiri method class VIII-B inlearn, with the project and grade control VIII-C (control) inlearn. to traditional methods. Research instruments using instrument with the capacity to think critically using tests. multiple choices. Data analysis techniques ( anakova) kovariat using analysis on significant standard $\alpha=0,05$ using SPSS 21.0. Research shows that there are significant influence the learning methods he continued on ability to think critically $(F=34,519 ; P=0,000)$. The ability to think critically students tutorial inquiry $(79,06 \pm 4,651)$ significantly higher than with the project $(72,06 \pm 4,134)$, and a traditional model $(69,70 \pm 5,459)$. As a follow up to the research is expected for teachers to apply terbimbing inkuiri learning model of matter the circulatory system in man in efforts to improve the ability of students think critically.

Keywords: think critically, Inquiry, Project, and Tradisional 


\section{PENDAHULUAN}

Proses pembelajaran pada dasarnya merupakan transformasi pengetahuan, sikap dan keterampilan dengan melibatkan aktivitas fisik dan mental siswa. Keterlibatan siswa baik secara fisik maupun mental merupakan bentuk pengalaman belajar siswa yang dapat memperkuat pemahaman siswa terhadap konsep pembelajaran. Guru sebagai tenaga pendidik profesional diharapkan mampu memilih dan menggunakan model yang sesuai dengan materi pelajaran sehingga dapat mengembangkan kemampuan berpikir kritis siswa.

Galbreath (dalam Arnyana, 2006) mengemukakan bahwa pengetahuan, modal intelektual, khususnya kecakapan berpikir tingkat tinggi (higher order thinking) terutama berpikir kritis, merupakan kebutuhan sebagai tenaga kerja yang handal. Afcariono (2008) juga menyatakan bahwa kemampuan berpikir tinggi khususnya berpikir kritis sangat penting diajarkan di sekolah karena keterampilan ini sangat diperlukan oleh siswa untuk sukses dalam kehidupannya. Oleh karena itu, seorang ahli pendidikan, John Dewey, sejak awal mengharapkan agar siswa diajarkan kecakapan berpikir kritis (Jhonson, 2002). Namun sampai saat ini, kecakapan berpikir kritis siswa belum ditangani secara sungguhsungguh oleh para guru di sekolah sehingga siswa masih banyak yang kurang terampil menggunakan kemampuan berpikir kritis yang berdampak pada hasil belajar siswa yang rendah. Hal ini mendukung pernyataan Ariyati (2010) bahwa rendahnya kualitas pendidikan disebabkan karena rendahnya kemampuan berpikir kritis siswa. Pada umumnya siswa diarahkan untuk menghafal dan menimbun informasi, sehingga siswa pintar secara teoritis tetapi miskin aplikasi. Akibatnya kemampuan berpikir kritis menjadi beku, bahkan menjadi susah untuk dikembangkan. Menurut Waspada (2007), pembelajaran biologi selama ini cenderung hanya mengasah aspek mengingat (remembering) dan memahami (understanding), yang merupakan low order of thinking. Wirtha \& Rapi (2008) mengungkapkan bahwa masih banyak siswa belajar hanya menghafal konsep-konsep, mencatat apa yang diceramahkan guru, pasif, dan jarang menggunakan pengetahuan awal sebagai dasar perencanaan pembelajaran. Menurut Trianto (2007) pengajaran keterampilan berpikir kritis di Indonesia memiliki beberapa kendala, salah satunya adalah dominasinya guru dalam proses pembelajaran dan tidak memberi akses pada peserta didik untuk berkembang secara mandiri melalui penemuan dan proses berpikirnya.

Berdasarkan Daftar Kumpulan Nilai (DKN) yang diperoleh dari guru bidang studi IPA di SMP Swasta HKBP Simantin Pane dapat disimpulkan bahwa hasil belajar siswa masih rendah dan terdapat beberapa siswa yang masih memperoleh nilai dibawah kriteria ketuntasan minimum (KKM) kemudian dengan observasi terhadap sekolah tersebut khususnya guru IPA, bahwa walaupun guru IPA disekolah tersebut telah berusaha menerapkan model yang bervariasi seperti ceramah, diskusi, tanya jawab, tetapi keaktifan siswa di kelas masih kurang memadai. Hal ini ditandai dengan minimnya aktivitas bertanya, menjawab, menanggapi dan mengemukakan pendapat, menalar, belum terbiasa belajar dengan diawali permasalahan-permasalahan dan menemukan sendiri apa yang mereka 
pelajari, sehingga kemampuan berpikir anak tidak dapat dimanfaatkan secara maksimal akibatnya hasil belajar yang dicapai oleh siswa masih jauh dari yang diharapkan. Lasmawan (dalam Anggareni, 2013) mengidentifikasi beberapa permasalahan pendidikan yaitu (1) pendidikan lebih menekankan perkembangan aspek kognitif dengan oerientasi penguasaan ilmu pengetahuan yang sebanyak-banyaknya dan mengabaikan perkembangan aspek afeksi dan aspek konasi, (2) pendidikan kirang memberikan perkembangan keterampilan proses, kemampuan berpikir kritis, (3) pendidikan kurang memberikan pengalaman yang nyata melalui pendekatan kurikulum dan pembelajaran terpadu. Sagala (2009), berpendapat juga bahwa pembelajaran yang berlangsung disekolah cenderung menunjukkan (1) guru lebih banyak ceramah, (2) pengelolaan pembelajaran cenderung klasikal dan kegiatan belajar kurang bervariasi, dan (3) guru dan buku sebagai sumber belajar. Dalam proses pembelajaran, peserta didik juga kurang didorong untuk mengembangkan kemampuan berpikir.

Rendahnya kemampuan berpikir kritis mengakibatkan siswa kurang dalam memahami menggunakan metode belajar yang sesuai sehingga belajar hanya secara hafalan dan merasa bosan. Rendahnya kemampuan berpikir kritis juga berdampak pada pemikiran siswa yang kurang sistematis atau kurang runtut. Hal ini dapat menyebabkan siswa sulit dalam memahami konsep-konsep biologi yang abstrak, yang berakibat pada rendahnya hasil belajar biologi. Pada PISA 2006, capaian sains untuk Indonesia berapa pada peringkat ke-50 dari 57 negara dengan skor 393. Pada PISA 2009, menunjukkan skor Indonesia kembali turun menjadi 383 dan menduduki peringkat ke-60 dari 65 negara. Pencapaian siswa Indonesia masih banyak berada pada level kemampuan dasar belum sampai pada level kemampuan yang lebih tinggi. Hasil dari TIMSS (Trends in International Mathematics and Science Study) IPA 2007, menyatakan bahwa Indonesia menduduki urutan ke-35 dari 49 negara, hasil PISA 2013 yang lebih memprihatinkan, Indonesia menempati urutan dua terbawah dari 65 negara (Anonim, 2013). Dengan melihat hasil riset tersebut, mencerminkan keadaan pendidikan di Indonesia sangat memprihatinkan dan tidak dapat dipungkiri bahwa sumber daya manusia Indonesia harus ditingkatkan lagi (Anggareni, 2013). Sistem peredaran darah pada manusia merupakan materi biologi yang membahas tentang peredaran darah dan gangguan pada sistem peredaran darah. Pada materi ini diperlukan keaktivan siswa dalam belajar dan berusaha menganalisis permasalahan yang ada dan mengatasi permasalahan tersebut. Siswa diharapkan dapat mencari dan menemukan konsep-konsep dalam sistem peredaran darah, serta dapat menyelesaikan permasalahanpermasalahan yang muncul dalam kehidupan sehari-hari. Agar dikelas menjadi efektif dan siswa terlibat secara aktif dalam proses pembelajaran, saat ini para peneliti bidang pendidikan telah mengembangkan sejumlah teori belajar dan berbagai metode yang dinilai baik dalam mendukung suasana aktif di dalam kelas. Metode yang berpusat pada siswa (student centered) dianggap tepat sebagai solusi terhadap permasalahan untuk meningkatkan hasil belajar biologi dan kemampuan berpikir kritis. Metode yang diharapkan mampu menjawab permasalahan tersebut dua diantaranya adalah dengan 
menggunakan metode inkuiri dan proyek.

Metode inkuiri melatih siswa dalam memecahkan masalah, meningkatkan pemahaman terhadap sains, mengembangkan keterampilan belajar sains, dan literasi sains serta melatih kecakapan berpikir siswa (Zion, 2007). Pembelajaran inkuiri merupakan suatu metode yang berpusat pada siswa, kelompok-kelompok siswa dihadapkan pada suatu persoalan atau mencari jawaban atas pertanyaanpertanyaan melalui suatu prosedur yang telah direncanakan secara jelas (Mustachifidoh, 2013). Aktivitas di laboratorium memiliki potensi untuk memberi peluang siswa belajar mengkonstruki pengetahuan sainsnya sambil bekerja, tetapi siswa mengalami kesulitan dalam mengintegrasikan konsep-konsep yang mereka pelajari dari guru dengan peristiwa-peristiwa yang mereka amati di laboratorium. Kesulitan-kesulitan tersebut disebabkan diantaranya oleh: (1) pemahaman yang kurang terhadap konsep-konsep yang mendasari percobaan,

ketidakmauan untuk menghubungkan hasil-hasil pengamatan dengan teori, dan (3) ketidakmauan untuk mengaitkan konsep-konsepyang dimiliki dengan hasil-hasil pengamatan dilaboratorium (Mustachifidoh, 2013).

Dengan menggunakan metode inkuiri dapat membantu siswa untuk mengintegrasikan konsep-konsep yang telah mereka ketahui sebelumnya dengan peristiwa-peristiwa yang mereka amati di laboratorium. Inkuiri juga dapat mengubah miskonsepsi yang dialami siswa menjadi konsep ilmiah. Belajar dengan menggunakan metode inkuiri diharapkan siswa menjadi lebih kreatif, inovatif, dan belajarnya menjadi lebih bermakna sehingga prestasi belajar biologi dapat ditingkatkan. Hal ini dikarenakan proses belajar inkuiri mengandung proses-proses mental yang lebih tinggi tingkatannya, misalnya merumuskan masalah, merancang percobaan, melakukan eksperimen, mengumpulkan dan menganalisis data, menarik kesimpulan, memiliki sifatsifat objektif, jujur, hasrat ingin tahu, dan keterbukaan. Siswa diharapkan dapat menumbuhkan motivasi dan memberi kesempatan banyak kepada siswa untuk mengambil peran sebagai ilmuwan, sehingga akan timbul kebanggaan dan harga diri dengan mengetahui hasil pekerjaan, memahami tujuan yang harus dicapai, akan mendorong siswa untuk lebih giat belajar, melahirkan hasil belajar yang bermakna sehingga hasilnya akan bermakna bagi subjek belajar. Dengan kelebihan yang ada dalam inkuiri, maka perlu diterapkan model ini di sekolah sebagai solusi agar siswa lebih diberdayakan dan aktif dalam aktivitas belajar sehingga dapat melatih kemampuan berpikir kritis yang diharapkan dapat bermanfaat dalam kehidupan sehari-hari.

Penelitian-penelitian yang
menggunakan metode inkuiri memberikan hasil bahwa metode inkuiri dapat meningkatkan hasil belajar dan motivasi siswa. Kemampuan berpikir kritis juga memberikan pengaruh dalam proses belajar, hal ini dibuktikan dalam hasil penelitian yang dilakukan Lubis (2012), dan Fitrah (2012). Penelitian yang menunjukkan lemahnya kemampuan berpikir kritis, antara lain: Rofi'udin (dalam Arnyana, 2007), menemukan bahwa terjadi keluhan tentang rendahnya kemampuan berpikir kritis dan kreatif yang dimiliki oleh lulusan pendidikan dasar. Disisi lain, ujian nasional yang selalu dimonopoli oleh produk sains, dan mengabaikan proses sains, menyebabkan rendahnya 
kemampuan siswa untuk mengeksplorasi kemampuannya dalam kinerja ilmiah.

Keyakinan akan keunggulan inkuiri dalam pembelajaran biologi didukung oleh pernyataan Bruner (dalam Amin, 1987) yang menyatakan keuntungan mengajar dengan model inkuiri adalah : (1) siswa akan memahami konsep-konsep dasar dan ide-ide yang lebih baik, (2) membantu siswa dalam menggunakan daya ingat dan transfer pada situasi-situasi proses belajar yang baru, (3) mendorong siswa untuk berpikir dan bekerja atas inisiatif sendiri, dan (4) mendorong siswa berpikir inisiatif dan merumuskan hipotesanya sendiri. Selain itu, pembelajaran menjadi student center, membentuk dan mengembangkan konsep diri, dapat mengembangkan bakat kemampuan individu, dapat menghindari cara-cara belajar tradisional (menghafal dan menerima informasi) serta memberikan waktu bagi siswa untuk mengasimilasi dan mengakomodasi informasi. Lawson (2000) juga menyebutkan bahwa pembelajaran biologi pada sekolah menengah dengan kurikulum berbasis inkuiri dapat mengembangkan berpikir kritis dan penguasan konsep. Setiawan (2005), dalam penelitiannya yang berjudul Pengaruh Pembelajaran Kontekstual dalam Strategi Inkuiri dan Pembelajaran Berdasarkan Masalah untuk Meningkatkan Kemampuan Berpikir dan Penguasaan KonsepKonsep Biologi Siswa SMP di Kecamatan Buleleng Bali menyimpulkan pembelajaran inkuiri berpengaruh secara signifikan terhadap kemampuan penguasaan konsepkonsep biologi. Anggareni, (2012), dalam penelitiannya yang berjudul "Implementasi Strategi Pembelajaran Inkuiri Terhadap Kemampuan Berpikir Kritis dan Pemahaman

Konsep IPA Siswa SMP" menemukan bahwa terdapat perbedaan kemampuan berpikir kritis dan pemahaman konsep antara kelompok siswa yang belajar dengan strategi pembelajaran inkuiri dibandingkan kelompok siswa yang belajar dengan strategi pembelajaran langsung.

Sementara itu metode pembelajaran proyek (project based learning) adalah sebuah metode pembelajaran yang menggunakan proyek (kegiatan) sebagai inti pembelajaran. Dalam kegiatan ini, siswa melakukan eksplorasi, penilaian, interpretasi, dan sintesis informasi untuk memperoleh berbagai hasil belajar. Metode Pembelajaran Berbasis Proyek merupakan suatu model pembelajaran yang menyangkut pemusatan pertanyaan dan masalah bermakna, pemecahan masalah, pengambilan keputusan, proses pencarian berbagai sumber, pemberian kesempatan kepada anggota untuk bekerja secara kolaborasi, dan menutup dengan presentasi produk nyata. Metode Pembelajaran Berbasis Proyek berfokus pada konsep dan prinsip inti sebuah disiplin, memfasilitasi siswa untuk berinvestigasi, pemecahan masalah, dan tugas-tugas bermakna lainnya, berpusat pada siswa (students center) dan menghasilkan produk nyata. Metode Pembelajaran Berbasis Proyek juga dapat meningkatkan keyakinan diri para siswa, motivasi untuk belajar, kemampuan kreatif, dan mengagumi diri sendiri (Santyasa, 2006). Menurut Sani (2013), pembelajaran berbasis proyek mendukung tercapainya tujuan pembelajaran biologi, megingat pembelajaran berbasis proyek merupakan pembelajaran yang komprehensif mengikutsertakan siswa 
melakukan investigasi secara

kolaboratif.

Sementara itu menurut hasil penelitian Yunita (2010) bahwa metode pembelajaran berbasis proyek (project based learning) juga sangat berpengaruh terhadap hasil belajar dan aktivitas siswa yaitu peningkatan hasil belajar siswa dan peningkatan aktivitas siswa. Menurut Thomas (dalam Wena, 2008), pembelajaran berbasis proyek merupakan model pembelajaran yang memberikan kesempatan kepada guru untuk mengelola pembelajaran di kelas dengan melibatkan kerja proyek. Depdiknas (2003: 7), menegaskan bahwa "pembelajaran berbasis proyek/tugas terstruktur (project-based learning) merupakan pendekatan pembelajaran yang membutuhkan suatu pembelajaran yang komprehensif dimana lingkungan belajar siswa (kelas) didesain agar siswa dapat melakukan penyelidikan terhadap masalah autentik termasuk pendalaman materi suatu materi pembelajaran, dan melaksanakan tugas bermakna lainnya".

Proyek dalam pembelajaran berbasis proyek tidak ditentukan oleh hasil belajar yang didapatkan oleh siswa saja, namun juga dilihat pada proses dan aktivitas siswa dalam proses pembelajaran sehingga akan berdampak pada meningkatnya hasil belajar siswa.

Pembelajaran dengan keterampilan proses sains juga sangat jarang dilaksanakan untuk sekolah menengah pertama sehingga menyebabkan tidak berkembangnya tingkat berpikir kritis siswa dalam pembelajaran biologi. Keterampilan proses melibatkan keterampilanketerampilan kognitif atau intelektual, manual, dan sosial. Keterampilan kognitif atau intelektual dengan melakukan keterampilan proses siswa

menggunakan pemikirannya, keterampilan manual terlibat dalam penggunaan alat dan bahan, pengukuran, penyusunan atau perakitan alat, keterampilan sosial dimaksudkan bahwa dengan keterampilan proses sains siswa berinteraksi dengan sesamanya dalam melaksanakan kegiatan belajar mengajar (Rustaman, 2009).

Berdasarkan uraian permasalahan di atas, maka dipandang perlu untuk melakukan suatu penelitian tentang penggunaan model pembelajaran inkuiri dan proyek dan pengaruhnya terhadap hasil belajar biologi, kemampuan berpikir kritis, dan keterampilan proses sains siswa di SMP Swasta HKBP Simantin Pane. Dan sebagai pembanding digunakan model pembelajaran tradisional (konvensional).

\section{METODE PENELITIAN}

\section{Lokasi dan Waktu Penelitian}

Penelitian ini telah dilakukan di kelas VIII SMP Swasta HKBP Simantin Pane, Kecamatan Panei Kabupaten Simalungun yang telah dilaksanakan pada bulan April sampai dengan Mei 2015.

\section{Populasi dan Sampel Penelitian}

Populasi dalam penelitian ini adalah seluruh siswa kelas VIII SMP Swasta HKBP Simantin Pane, Kecamatan Panei Kabupaten Simalungun tahun pelajaran 2014/2015 yang berjumlah 98 orang dan terdiri dari tiga kelas paralel.

Teknik pengambilan sampel menggunakan teknik total sampling, yaitu teknik penentuan sampel dengan mengambil seluruh anggota populasi sebagai responden atau sampel (Sugiyono, 2009). Sampel yang diambil peneliti adalah seluruh jumlah 
siswayang terdiri dari tiga kelas, dimana dua kelas eksperimen dengan rincian siswa kelas VIII-A (Inkuiri Terbimbing) berjumlah 34 orang, kelas VIII-B (Proyek) berjumlah 34 orang dan kelas VIII-C (Tradisional) berjumlah 30 orang.

\section{Jenis dan Desain Penelitian}

Penelitian ini termasuk penelitian quasi eksperimen.Desain yang digunakan dalam penelitian ini adalah nonequivalent control group design atau non randomized control pretest posttest design, artinya kelompok eksperimen maupun kelompok kontrol tidak dipilih secara random. Dalam desain ini, baik kelompok eksperimen maupun kelompok kontrol dibandingkan, kemudian kelompok yang ada diberi pretest, selanjutnya diberikan perlakuan, kemudian diberikan posttest.

Tabel 1. Desain Penelitian

\begin{tabular}{lccc}
\hline Kelompok & Pretest & Perlakuan & Posttest \\
\hline $\mathrm{A}$ & $\mathrm{T}$ & $\mathrm{X}_{1}$ & $\mathrm{~T}$ \\
$\mathrm{~B}$ & $\mathrm{~T}$ & $\mathrm{X}_{2}$ & $\mathrm{~T}$ \\
$\mathrm{C}$ & $\mathrm{T}$ & $\mathrm{X}_{3}$ & $\mathrm{~T}$ \\
\hline
\end{tabular}

Keterangan:
A : Kelompok yang dibelajarkan dengan metode Inkuiri terbimbing
B : Kelompok yang dibelajarkan dengan metode proyek
C : Kelompok yang dibelajarkan dengan metode konvensional
$\mathrm{T}$ : Kemampuan berpikir kritis siswa
$\mathrm{X}_{1}$ : Perlakuan dengan metode Inkuiri terbimbing(Eksperimen)
$\mathrm{X}_{2}$ : Perlakuan dengan metode Proyek (Eksperimen)
$\mathrm{X}_{3}$ : Perlakuan dengan metode Tradisional (Kontrol)

\section{Variabel Penelitian}

Dalam penelitian ini ada dua variabel yaitu variabel bebas dan variabel terikat.Yang menjadi variabel bebas adalah metode pembelajaran Inkuiri Terbimbing, Proyek, dan Tradisional. Variabel terikatnya adalah kemampuan berpikir kritis.

\section{Teknik Analisis Data}

Analisis data penelitian dilakukan terhadap dua hal pokok yaitu uji persyaratan dan pengujian hipotesis, dengan langkah-langkah sebagai berikut:

1. Mengkonversikan skor perolehan siswa ke dalam nilai skala 1-100, dengan rumus (Arikunto, 2003):

Nilai

$=\frac{\text { Jumlah skor yang diperoleh siswa }}{\text { Skor Maksimum }} \times 100$

2. Menghitung rata-rata untuk masing-masing variabel dengan rumus (Sudjana, 1992):

$\overline{\mathrm{X}}=\frac{\sum \mathrm{X}_{\mathrm{i}}}{\mathrm{n}}$

3. Menentukan simpangan baku masing-masing variabel dengan rumus (Sudjana, 1992):

$\mathrm{S}_{\mathrm{D}}=\sqrt{\frac{\mathrm{n} \sum \mathrm{X}_{\mathrm{i}}^{2}-\left(\sum \mathrm{X}_{\mathrm{i}}\right)^{2}}{\mathrm{n}(\mathrm{n}-1)}}$

4. Pengujian Normalitas Data

Uji normalitas data dilakukan untuk memeriksa apakah data sampel yang diperoleh dari populasi memiliki sebaran berdistribusi normal atau tidak. Uji normalitas data dianalisis dengan uji Lilliefors (Sudjana, 1992), atau dengan pendekatan KolmogorovSmirnov menggunakan program SPSS 21.0 for windows.

5. Pengujian Homogenitas

Uji homogenitas bertujuan untuk menguji apakah kelompokkelompok yang dijadikan sampel penelitian berasal dari populasi yang sama, artinya penyebarannya dalam populasi bersifat homogeny. Untuk mengetahuinya digunakan uji Fisher (Sudjana, 1992), atau 
menggunakan

pendekatan

Levene's Test dengan bantuan program SPSS 21 for windows.

6. Pengujian Hipotesis

Setelah persyaratan terpenuhi (normalitas dan homogenitas) selanjutnya dilakukan pengujian hipotesis.

Uji hipotesis pertama menggunakan analisis kovariat (anacova) untuk mengetahui hasil belajar, kemampuan berpikir kritis, dan keterampilan proses sains siswa (Supardi, 2013). Data hasil belajar adalah selisih data hasil postest setiap kegiatan pembelajaran dengan instrumen tes hasil belajar, kemampuan berpikir kritis, dan keterampilan proses sains. Jika hasil analisis menggambarkan adanya pengaruh yang signifikan antara ketiga kelas dengan perlakuan yang berbeda tersebut, maka dilakukan uji lanjut dengan uji Tukey untuk data aktivitas dan parameter estimated untuk hasil belajar biologi siswa. Seluruh analisis data dilakukan dengan menggunakan program SPSS 21 for windows.

\section{HASIL PENELITIAN}

\section{Deskripsi Hasil Penelitian}

Data pretest berpikir kritis siswa pada kelas metode inkuiri terbimbing dari 34 siswa diperoleh rata-rata nilai dan standar deviasi sebesar 27,88 $\pm 8,15$ sedangkan data pretest berpikir kritis siswa pada kelas metode proyek dari 34 siswa diperoleh rata-rata nilai dan standar deviasi sebesar 29,50 $\pm 8,71$ dan data pretest berpikir kritis siswa pada kelas metode tradisional dari 30 siswa diperoleh rata-rata nilai dan

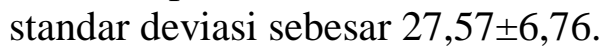

Data posttest berpikir kritis siswa pada kelas metode inkuiri terbimbing dari 34 siswa diperoleh rata-rata nilai dan standar deviasi sebesar
$79,32 \pm 4,28$ sedangkan data posttest berpikir kritis siswa pada kelas metode proyek dari 34 siswa diperoleh rata-rata nilai dan standar deviasi sebesar $72,06 \pm 4,13$ dan data posttest berpikir kritis siswa pada kelas metode tradisional dari 30 siswa diperoleh ratarata nilai dan standar deviasi sebesar $69,70 \pm 5,45$.

\section{Uji Normalitas}

Sebaran data pretest dan posttest berpikir kritis siswa yang dibelajarkan dengan metode inkuiri terbimbing, proyek, dan tradisional dapat dilihat pada Tabel 2 berikut:

Tabel 2. Uji normalitas data pretest dan posttest berpikir kritis siswa

\begin{tabular}{ccccc}
\hline \multirow{2}{*}{ Metode } & \multicolumn{4}{c}{ Kolmogorov-Smirnov } \\
\cline { 2 - 5 } & Sig. & Keterangan & Sig & Keterangan \\
\cline { 2 - 5 } Inkuiri & 0,11 & Normal & 0,24 & Normal \\
terbimbing & 0,18 & Normal & 0,25 & Normal \\
Proyek & 0,20 & Normal & 0,23 & Normal \\
Tradisional & \multirow{2}{*}{ Tradest } & \\
\hline
\end{tabular}

Dari tabel di atas, bahwa hasil pengujian normalitas data terhadap pretest dan posttest kemampuan berpikir kritis siswa dari setiap kelas metode inkuiri terbimbing, proyek, dan tradisional menunjukkan bahwa sebaran data berdistribusi normal $(\mathrm{P}>0,05)$.

\section{Uji Homogenitas}

Hasil uji homogenitas data pretest kemampuan berpikir kritis siswa juga dinyatakan homogen $(\mathrm{P}=$ $0,18>0,05)$ dan data posttest kemampuan berpikir kritis siswa juga dinyatakan homogen $(\mathrm{P}=0,703>0,05)$.

\section{Analisis Data}

Pengujian hipotesis dilakukan dengan teknik Analisis Kovariat (Anacova) untuk kemampuan berpikir kritis siswa berdasarkan data pretest dan posttest. 


\section{Pengaruh Metode Pembelajaran terhadap Kemampuan Berpikir Kritis Siswa}

Hasil analisis kovariat (Anacova) dengan bantuan SPSS 21.0 menunjukkan bahwa metode pembelajaran secara signifikan berpengaruh terhadap kemampuan berpikir kritis siswa $(\mathrm{F}=34,51$; $\mathrm{P}=0,000)$ dan kemampuan awal berpikir kritis siswa (pretest) tidak berkorelasi dengan nilai kemampuan berpikir kritis $(\mathrm{F}=0,73 ; \mathrm{P}=0,39)$. Selanjutnya hasil uji Tukey menunjukkan bahwa kemampuan berpikir kritis siswa yang dibelajarkan dengan metode Inkuiri Terbimbing $79,06 \pm 4,65(\bar{X} \pm S B)$,secara signifikan lebih tinggi dibandingkan dengan kemampuan berpikir kritis siswa yang dibelajarkan dengan metode proyek $72,06 \pm 4,13(\bar{X} \pm S B)$,maupun yang dibelajarkan dengan metode tradisional $69,70 \pm 5,45(\bar{X} \pm S B)$, (Gambar 1).

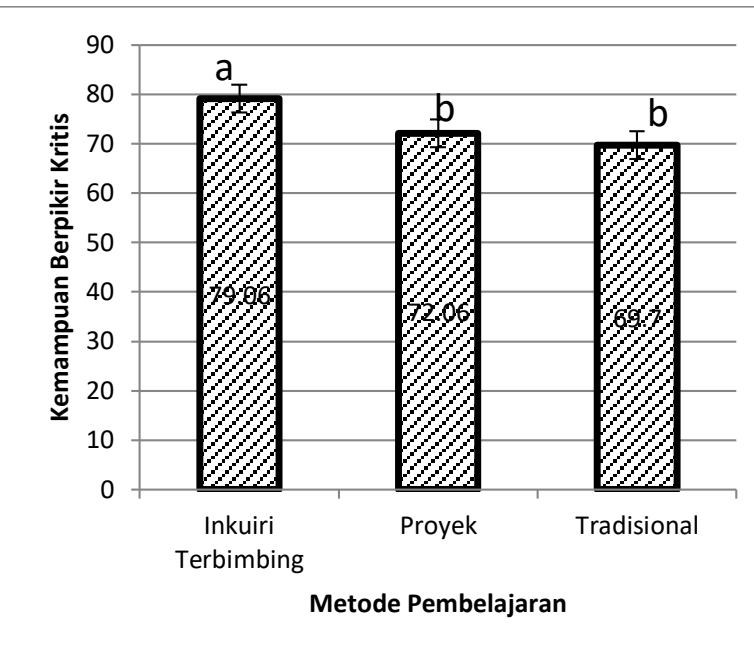

Gambar 1. Pengaruh Metode Inkuiri Terbimbing, Proyek dan Tradisional terhadap Kemampuan Berpikir Kritis Siswa kelas VIII SMP Swasta HKBP Simantin Pane $(\mathrm{F}=34,51 ; \mathrm{P}=0,000)$

\section{PEMBAHASAN}

\section{Pengaruh Metode Pembelajaran terhadap Kemampuan Berpikir Kritis}

Pengaruh penggunaan metode pembelajaran terhadap kemampuan berpikir kritis siswa yang dianalisis dengan teknik analisis kovariat (Anakova). Hasil analisis kovariat diperoleh $F_{\text {hitung }}>F_{\text {tabel }}$ yaitu 34,51>3,09 serta nilai probalilitas $0,000<0,05$. Dengan demikian, terima $\mathrm{H}_{\mathrm{a}}$ atau tolak $\mathrm{H}_{0}$ sehingga disimpulkan ada pengaruh yang signifikan antara penggunaan metode Inkuiri Terbimbing, Proyek, dan Tradisional terhadap kemampuan berpikir kritis siswa pada materi sistem peredaran darah pada manusia kelas VIII SMP Swasta HKBP Simantin Pane. Selanjutnya hasil uji lanujut dengan menggunakan uji Tukey's menunjukkan bahwa rata-rata kemampuan berpikir kritis siswa yang dibelajarkan dengan metode Inkuiri Terbimbing $\quad 79,06 \pm \quad 4,65 \quad(\bar{X} \pm$ $S B$ ),secara signifikan lebih tinggi dibandingkan dengan kemampuan berpikir kritis siswa dengan metode proyek 72,06 $\pm 4,13(\bar{X} \pm S B)$,maupun kemampuan berpikir kritis siswa yang menggunakan metode tradisional 69,70 $\pm 5,45(\bar{X} \pm S B)$.

Hal ini sesuai dengan penelitian yang dilakukan oleh Susanti (2013) yang menyatakan bahwa pembelajaran yang menggunakan inkuiri terbimbing terbukti meningkatkan kemampuan berpikir kritis siswa dan menunjukkan kemampuan berinkuiri yang sangat baik meliputi aspek inkuiri diantaranya merumuskan masalah, merumuskan hipotesis, mengumpulkan data dan membuat kesimpulan. Sependapat dengan hasil penelitian Laurina (2007) yang menyimpulkan bahwa terdapat perbedaan kemampuan berpikir kritis dan hasil belajar siswa yang signifikan antara pembelajaran dengan model 
inkuiri terbimbing dan konvensional, yang berarti penerapan model inkuiri terbimbing lebih efektif dalam meningkatkan kemampuan berpikir kritis dan hasil belajar siswa.

Keseluruhan kegiatan yang dilakukan siswa dalam kelas inkuiri terbimbing memberikan kesempatan yang luas dikarenakan mereka terlibat aktif dalam proses pembelajaran, tetapi pada kelas proyek tidak semua siswa termotivasi untuk lebih aktif, hanya beberapa siswa yang pintar yang antusias dalam memecahkan masalah sedangakn sebagian lagi tidak ikut berpartisipasi. Siswa di kelas inkuiri terbimbing lebih aktif bertanya, aktif menjawab pertanyaan, aktif menanggapi masalah yang muncul, dan aktif mencari informasi tentang siswa peredaran darah pada manusia dari semua berbagai sumber belajar. Mereka aktif juga melakuan diskusi secara terbimbing, aktif mencatat halhal yang penting masalah sistem peredaran darah pada manusia untuk dapat dipelajari kembali di rumah, secara aktif berkomunikasi yaitu saling berbagi informasi dan melakukan diskusi tentang inkuiri terbimbing dalam kelompok belajar, sedangkan siswa di kelas proyek karena bimbingan yang diberikan oleh guru lebih sedikit, siswa masih banyak yang merasa bingung terhadap apa yang marus mereka kerjakan.

\section{Penilaian}

instrumen

kemampuan berpikir kritis dilakukan dengan penskoran, yaitu skor 1 untuk pilihan jawaban benar tanpa menggunakan alasan, skor 2 untuk pilihan jawaban benar dengan alasan singkat, dan dkor 3 untuk pilihan jawaban benar dengan alasan yang benar dan lengkap. Siswa yang dibelajarkan dengan metode inkuiri terbimbing dalam menjawab soal tes berpikir kritis lebih sering mendapat skor 3 yaitu siswa yang menjawab pilihan benar dan dengan alasan yang lengkap, sedangkan siswa yang dibelajrkan dengan metode proyek lebih sering mandapat skor 2 yang hanya memberikan alasan singkat. Hal ini disebabkan karena kemampuan siswa SMP masih kurang dalam mengembangkan kemampuan berpikir kritisnya, meskipun sudah dibelajarkan dengan metode proyek, kemudian karena kemampuan berpikir kritis siswa SMP yang masih dalam level rendah, jadi siswa sangat membutuhkan pengarahan dan bimbingan selama proses pembelajaran berlangsung.

Kesimpulan diatas sekaligus mendukung hasil penelitian Nuangchalaren (2009) yang menyatakan model pembelajaran inkuiri dapat meningkatkan pengetahuan kognitif siswa, keaktifan siswa dan memacu penalaran kemampuan berpikir kritis serta dapat meningkatkan kepercayaan diri (self believe) serta kepuasan belajar. Quitadamoet al. (2008) melaporkan bahwa pembelajaran dengan menggunakan CBI (Community Based Inquiry) menunjukkan peningkatan kemampuan berpikir kritis siswa secara signifikan dibandingkan dengan siswa kelompok tradisional dan kelompok gabungan tradisional-CBI.Brickman, et al. (2009) dalam studi mereka di Universitas Georgia menunjukkan perbaikan dan peningkatan yang lebih besar dalam literasi sains dan keterampilan penelitian siswa menggunakan metode pembelajaran inkuiri di laboratorium.Mereka juga menemukan bahwa siswa yang dibelajarkan dengan metode inkuiri memiliki kepercayaan diri (confidence) lebih besar dalam mengasah kemampuan ilmiah daripada siswa yang dibelajarkan secara tradisional. 
Pembelajaran inkuiri pada dasarnya suatu cara memecahkan masalah nyata yang berasal dari individu dalam sebuah kelompok dengan menumbuhkan keterampilan siswa, memandirikan siswa, meningkatkan kepercayaan diri siswa serta membuka pola piker siswa sehingga mampu mengembangkan kemampuan yang dimilikinya. Pembelajaran inkuiri bermanfaat untuk mengajak dan mengajarkan kepada siswa agar siswa aktif dalam proses pembelajaran melalui pengalaman nyata.

Metode inkuiri menjadikan siswa lebih aktif dalam mencari dan menemukan sendiri pemecahan masalah yang diberikan kepada mereka. Kelompok siswa yang dibelajarkan dengan pembelajaran tradisional, proses pembelajaran cenderung berpusat pada guru dengan menggunakan metode ceramah. Selama proses pembelajaran, kemampuan berpikir kritis siswa kurang dikembangkan, karena siswa lebih banyak belajar secara individual dengan menerima, mencatat, dan menghafal materi pelajaran yang diterimanya dari guru sebagai penentu jalannya proses pembelajaran.

Dengan demikian, berdasarkan hasil penelitian, pengujian statistik dan teoriteori yang ada terbukti bahwa kelompok siswa yang dibelajarkan dengan metode inkuiri terbimbing memberikan pengaruh yang lebih baik dalam merangsang dan mengembangkan kemampuan berpikir kritis siswa.

\section{KESIMPULAN}

Berdasarkan hasil penelitian dan pembahasan, maka diperoleh kesimpulan bahwa ada pengaruh yang signifikan antara penggunaan metode inkuiri terbimbing, proyek dan tradisional terhadap kemampuan berpikir kritis siswa pada materi sistem peredaran darah pada manusia di kelas VIII SMP Swasta HKBP Simantin Pane. Kemampuan berpikir kritis siswa yang dibelajarkan dengan metode inkuiri terbimbing secara signifikan lebih tinggi dibandingkan dengan metode proyek dan metode tradisional.

\section{DAFTAR PUSTAKA}

Afcariono, M. 2008. Penerapan Pembelajaran berbasis Masalah untuk Meningkatkan Kemampuan Berpikir Kritis Siswa pada Mata Pelajaran Biologi. Jurnal Pendidikan Inovatif, 3(2) : 65-68.

Ariyati, E. 2010. Pembelajaran Berbasis Praktikum untuk Meningkatkan Kemampuan Berpikir Kritis Mahasiswa. Jurnal Matematika dan IPA, 1(2) : 1-11.

Brickman, P., C. Gormally, N. Armstrong, B. Hallar. 2009. Effects of Inquiry based Learning on Students' Science Literacy Skills and Confidence. International Journal for the Scholarship of Teaching and Learning, 3(2):1-22.

Bruner, J. 1986.Actual minds, possible worlds. Cambridge, MA: Harvard University.

Ennis, R. H., W. L. Gardiner, R. Morrow, D. Paulus, dan L. Ringel. 1964. The Cornell Clas-Reasoning Test, Form X. Champaign: Illinois 
Critical Thinking Project, Department of Edicational Policy Studies, University of Illinois at Urbana-Champaign.

Fitrah. 2012. Pengaruh Model Pembelajaran Kooperatif Tipe STAD Menggunakan Media Vidio Pembelajaran Terhadap Hasil Belajar dan Kemampuan Berpikir Kritis Mahasiswa Biologi Universitas Negeri Medan, Medan: Program Pascasarjana Unimed.

Galbreath, J. 1999. Preparing the $21^{\text {st }}$ Century Worker: The Link Between Computer-Based Technology and Future Skill Sets. Educational

Technology.Desember: 14-22.

Jhonson, E. B. 2002. Contextual Teaching and Learning. California: Corwin Press, Inc.

Jufri, 2013. Belajar dan Pembelajaran

Sains. Bandung: Pustaka Reka Cipta

Lasmawan, I Wayan. 1997. Pengembangan Model Belajar Cooperative Learning dalam Pembelajaran di Sekolah Dasar (Studi Pengembangan IPS di SD Kota Bangli-Bali Kelas V). Tesis Program Pasca Sarjana UPI: Tidak Diterbitkan.

Laurina. 2007. Efektifitas Penerapan Model Inkuiri Terbimbing Untuk Meningkatkan Kemampuan Berpikir Kritis Siswa Kelas X SMAN Pademawu Pamekasan.
Skripsi (diakses November 2013)

di

http://karyailmiah.um.ac.id/index.p hp/kimia/article/view/3098.

Lawson, A.E. 2000. Managing the Inquiry Classroom: Problem and Solutions. The America Biology Teacher. 62 (9) ;641-648.

Lubis, J. 2012. Pengaruh Penerapan Metode Pembelajaran Problem Solving Menggunakan Video Pembelajaran dan Camtasia Terhadap Hasil Belajar dan Kemampuan Berpikir Kritis Mahasiswa Tentang Kultur Jaringan di Universitas Muhammadiyah Tapanuli Selatan. Medan: Program Pascasarjana Unimed.

Mustaji. 2013. Pengembangan Kemamupan Berpikir Kritis dan Kreatif dalam Pembelajaran. Artikel (diakses pada 9 April 2013) di http://www.tp.ac.id.

Quitadamo, I. J., C. L. Faiola, J. E. Johnson, and M. J. Kurtz. 2008. Community-based Inquiry Improves Critical Thinking in General Education Biology. Article. CBE-Life Sciences Education, (7) : 327-337.

Sagala, S. 2009. Konsep dan Makna Pembelajaran. Bandung: Alfabeta. Trianto, 2007. Model-model Pembelajaran Inovatif 
Berorientasi Konstruktivistik.

Jakarta: Prestasi Pustaka.

Wirtha, I.M. \& Rapi, N.K. 2008.

Pengaruh Model Pembelajaran dan

Penalaran Formal Terhadap

Penguasaan Konsep Fisika dan

Sikap Ilmiah Siswa SMA Negeri 4

Singaraja. Jurnal Penelitian dan

Pengembangan Pendidikan

Lembaga Pendidikan Undiksha,

1(2): 15-29.

Bio-Lectura: Jurnal Pendidikan Biologi, Vol 7, No 1, April 2020 